\title{
Kajian Hubungan Arsitektur Pohon dan Kehadiran Burung di Kampus IPB Dramaga Bogor
}

\author{
MUHAMMAD CHOIRUDDIN AZIS ${ }^{1 *}$, TATI BUDIARTI'1, SYARTINILIA1 \\ 1. Departemen Arsitektur Lanskap, Fakultas Pertanian, Institut Pertanian Bogor \\ Jalan Meranti, Dramaga, Bogor 16680, Indonesia \\ *E-mail: m.choiruddin.azis@gmail.com
}

\section{ABSTRACT \\ Study of Correlation of Tree Architecture and Birds Presence in IPB Campus Dramaga Bogor}

Trees play a major role for creating the landscape characteristic and also functions as a habitat for many birds. Trees has characteristic created by canopy and branches shape. The research goals were to analyze the tree diversity based on its architecture, bird species richness, trees usage level by birds, and the influence given by tree architecture to bird presence. This research was conducted by divide IPB Dramaga campus into observation plots by size $300 \mathrm{~m} \times 300 \mathrm{~m}$. Then each plot was observed the trees physic include its canopy, branches, leaf size, flower and fruit existance and birds presence on the selected trees. In this research gained 99 sample trees that divided into 24 observation plots with 25 species of birds on the sample trees. From the result of analysis seen that parameter of the trees that influence bird presence are branches shape and flower existance, with model $Y=0,566+2,777 X_{1}+2,543 X_{2}$. From the reference and research result we knew that bird most prefered tree with vertical branch and have flower on it. From this research result also recommended some tree specieses that can attract more birds.

Keywords : birds habitat, observation plots, tree preference, trees

\section{Pendahuluan}

Pohon merupakan salah satu elemen lunak (softscape) yang sering digunakan dalam pengembangan suatu tapak. Bentuk pohon merupakan elemen desain yang paling memegang peranan dan harus dipertimbangkan dalam membuat perancangan lanskap (Booth 1983). Pohon dengan berbagai bentuk tajuknya berperan dalam membentuk karakter lanskap sebagai fungsi arsitektural. Percabangan pohon yang bervariasi dengan karakter yang unik juga dapat dimanfaatkan sebagai focal point di dalam tapak dan dapat menunjang karakter lanskap tertentu. Selain bentuk tajuk dan percabangan, keindahan suatu pohon juga dibentuk oleh daun, bunga dan buah. Ukuran, warna, dan bentuk daun menentukan fungsi suatu pohon di dalam lanskap, di samping itu juga mempengaruhi kehadiran burung ke pohon tersebut (MacKinnon 2010). Bunga adalah bagian yang sangat populer dalam identifikasi dan pemilihan pohon. Keberadaan buah dalam suatu lanskap 
tidak terlihat secara signifikan dan tidak ornamental, tetapi buah mempengaruhi kehadiran burung di pohon tersebut (Bridwell 2003).

Penggunaan pohon di dalam suatu lanskap juga memiliki fungsi ekologi, yaitu sebagai habitat dari berbagai jenis satwa. Salah satu jenis satwa yang sering berada di tapak atau lanskap adalah dari jenis burung. Burung memiliki pemilihan jenis pohon yang berbeda sesuai dengan faktor yang tersedia untuk mendukung kelangsungan hidupnya (Pettingill 1970). Penggunaan pohon bagi burung juga sangat beragam, sebagai sarang, shelter (tempat istirahat), tempat mencari pakan atau berburu, tempat berkembang biak, tempat bermain dan mengasuh anak (Welty 1982). Burung memanfaatkan bagian pohon yang berbeda-beda sesuai dengan kebutuhan, sehingga tipe pohon yang digunakan berpengaruh besar terhadap kelangsungan hidup burung di dalamnya. Menurut Perrins dan Birkhead (1983), suatu habitat yang baik untuk perkembangbiakan burung biasanya adalah habitat yang dapat memberikan potensi pakan yang cukup besar. Burung pada umumnya mudah dijumpai pada berbagai tipe strata, namun setiap strata mempunyai karakteristik tersendiri sehingga jenis burung yang ada pada setiap strata juga berbeda.

Saat ini belum banyak penelitian mengenai hubungan penggunaan pohon dengan berbagai model arsitekturnya terhadap keberadaan burung yang ada di dalam tapak. Dengan arsitektur yang berbeda, maka akan tercipta ruang berbeda juga sebagai habitat burung. Penelitian ini dilakukan untuk menguji variabel arsitektur pohon maupun faktor lain pada pohon yang berpengaruh terhadap jumlah jenis burung yang ada di pohon tersebut. Dengan demikian diharapkan ke depannya pemilihan pohon dalam penataan tapak atau lanskap tidak hanya mempertimbangkan aspek arsitektural tetapi juga memperhatikan kehidupan satwa khususnya burung yang nantinya akan menempati pohon tersebut.

Kampus IPB (Institut Pertanian Bogor) Dramaga memiliki banyak tegakan pohon dan sekitar 72 jenis burung (Kurnia 2003). Dengan demikian, kampus IPB Dramaga sangat sesuai untuk dijadikan sebagai lokasi penelitian ini yang membutuhkan pohon bertajuk sempurna sebagai salah satu variabel bebas utama serta keanekaragaman burung yang tinggi sebagai variabel terikat. Penelitian ini bertujuan (1) menganalisis keragaman pohon berdasarkan arsitektur tajuk dan percabangan, (2) menganalisis kekayaan spesies burung yang mendatangi pohon berdasarkan arsitekturnya, (3) menganalisis tingkat penggunaan pohon oleh burung, serta (4) menganalisis pengaruh aristektur pohon terhadap kehadiran burung di pohon tersebut.

\section{Metode}

\subsection{Waktu dan Lokasi Penelitian}

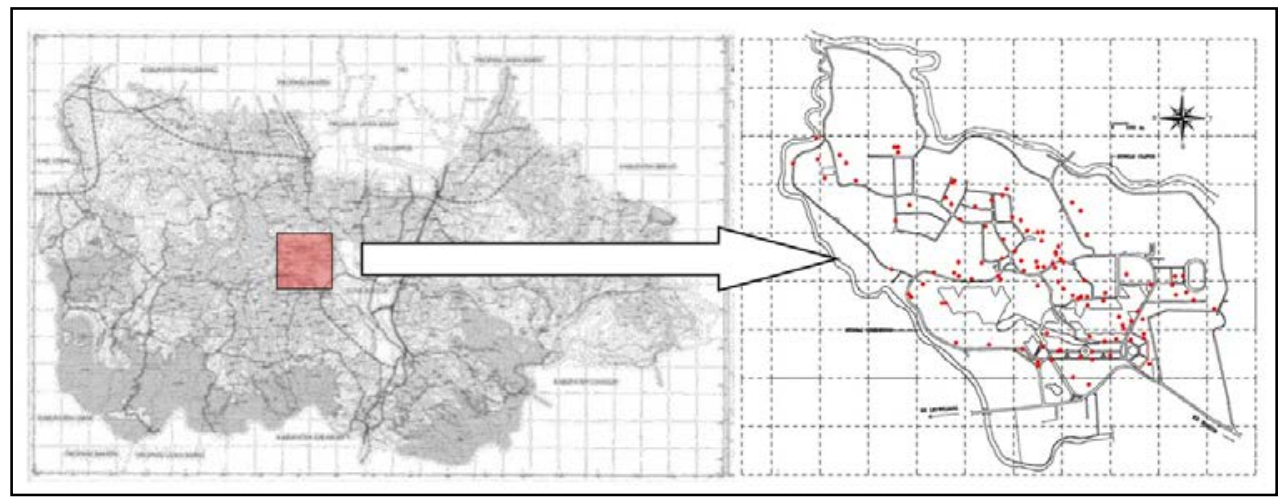

Gambar 2. Peta Orientasi Lokasi Penelitian 
Penelitian ini dilakukan pada Maret sampai Juni 2013 di Kampus IPB Dramaga, Desa Babakan, Kecamatan Dramaga, Kabupaten Bogor, Provinsi Jawa Barat (Gambar 2). Letak geografis antara 6o 32' 41" - 60 33' 58" LS, dan 106 42' 47" - $106^{\circ}$ 44' 07" BT. Penelitian ini meliputi tahap inventarisasi, analisis data, dan penyusunan sintesis (Gambar 3).

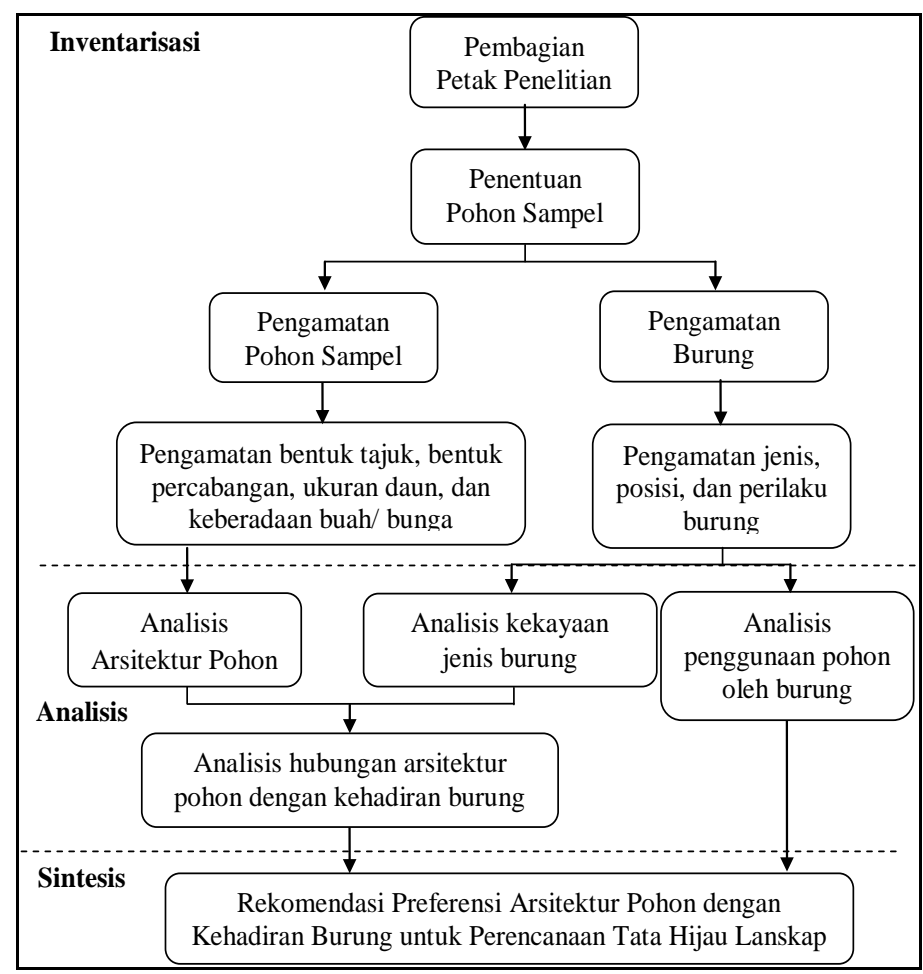

Gambar 3. Bagan Alir Penelitian

\subsection{Metode Pengumpulan Data}

\subsubsection{Komposisi pohon}

Pengamatan pohon yang dilakukan dimulai dengan membagi area kampus IPB Dramaga ke dalam petak-petak pengamatan yang berukuran 300 m×300 m. Dari setiap petak pengamatan dilakukan inventarisasi pohon dan diambil beberapa pohon yang dijadikan sampel. Kriteria pohon sampel harus memiliki tinggi lebih dari 6 meter dan ekspresi tajuk 80-100\% mendekati bentuk tajuk menurut Booth (1983). Data yang dikumpulkan dari pohon adalah bentuk tajuk (Booth 1983), bentuk percabangan (Stevens et al. 1994), ukuran daun, dan keberadaan bunga dan buah.

\subsubsection{Kekayaan jenis burung}

Pengamatan burung dilakukan dengan menggunakan metode Penghitungan dari Titik Hitung (Point Count for Birds) yang dianjurkan oleh Sutherlands (2001) dalam Darjono dan Duryati (2004). Pengamatan dilakukan dengan mencatat semua data perjumpaan dengan burung yang berada di pohon terpilih, mencakup jenis, lokasi keberadaannya di pohon, dan perilakunya ketika diamati.

\subsection{Metode Analisis Data}

\subsubsection{Analisis keragaman arsitektur pohon}

Arsitektur pohon sampel dianalisis secara deskriptif meliputi bentuk tajuk, bentuk percabangan, ukuran daun, dan keberadaan bunga serta buah. Data ini kemudian dibandingkan antar petak untuk mengetahui kecenderungan penggunaan pohon berdasarkan arsitekturnya di Kampus IPB Dramaga. 


\subsubsection{Analisis kekayaan jenis burung}

Analisis kekayaan jenis burung yang diamati diukur dengan Indeks Kekayaan Jenis Jackknife.

\subsubsection{Analisis Penggunaan Pohon oleh Burung}

Analisis terhadap penggunaan strata pohon oleh burung dilakukan secara deskriptif kualitatif, yaitu dengan menghubungkan antara persebaran vertikal jenis burung dengan arsitektur pohon yang didatangi.

\subsubsection{Analisis Hubungan Arsitektur Pohon dengan Kekayaan Jenis Burung}

Model persamaan regresi linier berganda yang digunakan sebagai berikut :

$$
Y=a+b_{1} X_{1}+b_{2} X_{2}+b_{3} X_{3}+b_{4} X_{4}+b_{5} X_{5}
$$

\author{
Keterangan: \\ $\mathrm{Y}=$ Jumlah jenis burung yang ditemukan \\ $a=$ Konstanta regresi \\ $b_{n}=$ Koefisien \\ $X_{1}=$ Variabel bentuk tajuk pohon
}

$X_{2}=$ Variabel bentuk percabangan pohon

$X_{3}=$ Variabel ukuran daun

$X_{4}=$ Variabel keberadaan bunga

$X_{5}=$ Variabel keberadaan buah

Pengolahan data dilakukan dengan menggunakan software SPSS Statistics 17.0. Dilakukan uji $F$ untuk mengetahui apakah model persamaan yang diajukan dapat diterima atau tidak. Jika $P<0,15$ maka model yang diajukan dapat diterima. Untuk menguji signifikansi konstanta dari setiap variabel independen, maka dilakukan uji t. Dengan hipotesis sebagai berikut :

$\mathrm{H}_{0}=$ Variabel bebas berpengaruh nyata terhadap variabel terikat

$\mathrm{H}_{1}=$ Variabel bebas tidak berpengaruh nyata terhadap variabel terikat

Dengan pengambilan keputusan sebagai berikut:

Jika probabilitas $<0,15$ maka terima $\mathrm{H}_{0}$

Jika probabilitas $>0,15$ maka tolak $\mathrm{H}_{0}$

\subsection{Sintesis}

Hasil dari penelitian ini diketahui parameter yang paling mempengaruhi kedatangan burung pada suatu pohon. Kemudian dengan model yang diajukan dapat ditentukan karakter pohon yang dapat mengundang burung, sesuai dengan variabel bebas model.

\section{Hasil dan Pembahasan}

\subsection{Hasil}

Hasil inventarisasi pohon didapatkan 99 individu pohon yang memiliki bentuk tajuk yang mendekati sempurna, tersebar dalam 24 petak di seluruh kampus IPB Dramaga. Keseluruhan pohon sampel yang diambil mewakili tujuh bentuk tajuk menurut Booth (1983), tetapi hanya mewakili empat bentuk percabangan menurut Stevens et al. (1994). Pengamatan burung pada pohon sampel dilakukan selama 18 hari pengamatan dan tiga kali pengulangan setiap harinya. Dalam pengamatan yang dilakukan berhasil ditemukan 25 jenis burung yang memanfaatkan pohon sampel secara langsung. Bentuk pemanfaatan pohon sampel oleh burung beragam, seperti untuk makan, bersarang, kawin, bermain, atau sekedar untuk bertengger. Data hasil penelitian dicantumkan pada Tabel 1. 
Tabel 1. Data hasil penelitian

\begin{tabular}{llccr}
\hline Parameter pohon & & Jumlah pohon & Jumlah jenis burung & $\begin{array}{l}\text { Tingkat penggunaan } \\
(\%)\end{array}$ \\
\hline \multirow{5}{*}{ Bentuk tajuk } & Columnar & 13 & 10 & 2,849 \\
& Fastigiate & 20 & 14 & 2,592 \\
& Picturesque & 5 & 10 & 7,407 \\
& Pyramidal & 6 & 5 & 3,086 \\
& Rounded & 42 & 24 & 2,116 \\
& Spreading & 11 & 12 & 4,04 \\
& Weeping & 2 & 4 & 7,407 \\
\hline \multirow{5}{*}{ Bentuk percabangan } & Horizontal & 27 & 14 & 1,921 \\
& Tortuous & 18 & 18 & 3,704 \\
& Vertical & 38 & 22 & 2,144 \\
& Weeping & 15 & 15 & 3,704 \\
& Pendulous & 0 & 0 & 0 \\
\hline \multirow{3}{*}{ Ukuran daun } & Besar & 22 & 12 & 2,02 \\
& Sedang & 44 & 19 & 1,599 \\
\hline \multirow{2}{*}{ Keberadaan bunga } & Kecil & 33 & 21 & 2,357 \\
\hline \multirow{2}{*}{ Keberadaan buah } & Ada & 19 & 16 & 3,119 \\
& Tidak & Ada & 23 & 1,065 \\
\hline
\end{tabular}

\subsection{Pembahasan}

\subsubsection{Keanekaragaman pohon}

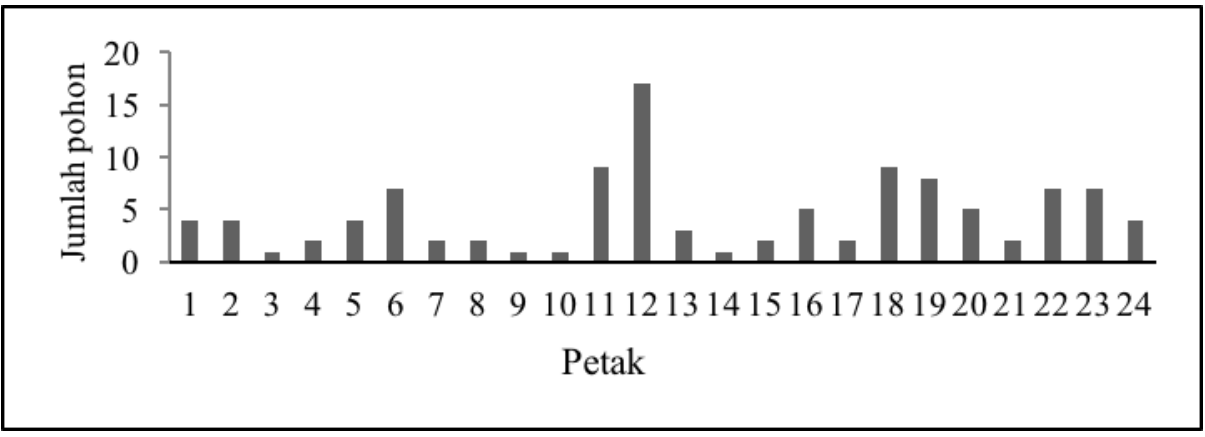

Gambar 4. Jumlah Pohon Sampel pada Masing-Masing Petak Pengamatan

Perbandingan komposisi pohon pada masing-masing petak pengamatan yang digunakan dapat dilihat pada Gambar 4. Tidak semua pohon yang ditanam di kawasan kampus IPB Dramaga memiliki tajuk yang terbentuk dengan sempurna. Hal ini karena sistem penanaman pohon yang kurang sesuai prosedur jarak tanam yang baik, sehingga masing-masing tajuk pohon saling berhimpitan dalam proses pertumbuhannya.

Selain itu pada kawasan kebun percobaan hanya bagian tepi jalan yang ditanami pohon. Beberapa area kampus juga masih berupa kebun karet yang homogen dan hutan yang memiliki tajuk rapat sehingga tidak bisa diambil sebagai pohon sampel.

Tajuk rounded adalah bentukan tajuk yang paling banyak ditemukan pada pohon sampel, yaitu 42 pohon. Tajuk rounded merupakan bentukan tajuk yang paling umum untuk pohon dan paling sering digunakan dalam penataan lanskap (Booth 1983). Di kawasan kampus IPB Dramaga hanya beberapa jenis pohon yang memiliki tajuk weeping, dan hanya dua pohon yang bisa diambil sebagai pohon sampel. Pada penelitian ini juga tidak ditemukan pohon yang memiliki percabangan pendulous, karena pendulous adalah salah satu bentukan percabangan yang unik dan hanya bisa ditemukan pada beberapa 
jenis conifer dan pohon (Stevens et al. 1994). Berdasarkan hasil tersebut dapat diperkirakan bahwa keanekaragaman pohon di kampus IPB Dramaga apabila ditinjau dari bentuk tajuknya adalah rendah, karena cenderung menggunakan pohon bertajuk rounded.

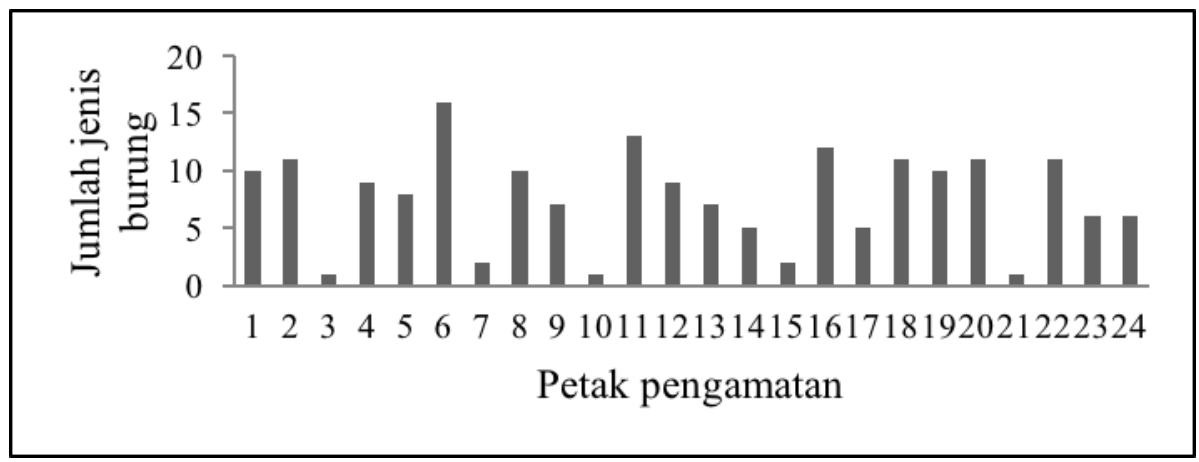

Gambar 5. Jumlah jenis burung pada masing-masing petak pengamatan

\subsubsection{Keanekaragaman jenis burung}

Data jumlah jenis burung pada setiap petak pengamatan disajikan pada Gambar 5 . Petak 6 adalah petak yang paling banyak dijumpai jenis burung di dalamnya, yaitu 16 jenis. Petak 6 ini berada di perumahan dosen yang ditanami vegetasi beranekaragam jenis dan tipe pertumbuhannya dari groundcover sampai pohon, sehingga jenis burung yang ada di dalamnya juga lebih beragam. Sedangkan petak 4, 10, dan 22 adalah petak yang paling sedikit jenis burungnya, dimana masing-masing hanya dijumpai satu jenis burung. Hal ini lebih dikarenakan faktor pada pohon sampel yang diambil tidak bisa menarik banyak jenis burung untuk datang.

Kekayaan jenis burung untuk seluruh pohon sampel yang dihitung menggunakan indeks kekayaan jenis Jacknife adalah $27,9 \pm 3,3$, sehingga jumlah jenis burung yang didapatkan 25 spesies masih masuk dalam selang nilai tersebut. Nilai kekayaan jenis dari Jacknife ini menunjukkan prediksi jumlah jenis satwa yang dapat ditemukan pada area pengamatan. Apabila dijumlahkan dengan burung yang ditemukan di luar pohon sampel, maka burung yang ditemukan selama penelitian berlangsung adalah 46 jenis. Tetapi angka ini tidak bisa mewakili jumlah jenis burung yang ada di seluruh kawasan kampus IPB Dramaga, karena penelitian hanya dilakukan di beberapa titik yang acak.

Jenis-jenis yang terlihat mencolok dapat beradaptasi dengan seluruh bentuk tajuk adalah cucak kutilang (Pycnonotus aurigaster), bondol jawa (Lonchura leucogastroides), dan bondol peking (Lonchura punctulata). Menurut Whitten et al. (1999) bahwa sebagian besar burung yang ada di daerah urban adalah pemakan biji-bijian di atas tanah daripada pemakan serangga pada batang atau tajuk pohon. Sebenarnya banyak jenis burung pemakan serangga yang ditemukan dalam waktu penelitian, dari 25 jenis burung yang ditemukan 10 jenis adalah pemakan serangga dan 5 jenis pemakan serangga sebagian. Tetapi ketiga jenis burung di atas terlihat mendominasi dan menyebar dengan merata karena populasi dan daya adaptasi yang lebih tinggi.

Sedangkan jenis-jenis yang hanya ditemukan pada satu jenis bentuk tajuk adalah cekakak sungai (Halcyon chloris), remetuk laut (Gerygone sulphurea), caladi tilik (Dendrocopos moluccensis), kowak malam abu (Nycticorax nycticorax), dan wiwik uncuing (Cacomantis sepulclaris). Cekakak sungai dan remetuk laut hanya ditemukan berada pada pohon sengon (Paraserianthes falcataria). Dalam dua kali perjumpaan, cekakak sungai selalu menggunakan pohon sengon sebagai pohon tenggeran. Demikian juga remetuk laut yang dalam tiga kali perjumpaan seluruhnya juga berada di pohon sengon untuk memakan 
serangga yang banyak terdapat di pohon. Caladi tilik anggota suku Picidae yang mengebor dan mencolok kulit batang pohon untuk mencari serangga dan tempayak (Mackinnon et al. 2010). Selama penelitian caladi tilik ditemukan berada pada pohon sengon, lamtoro (Leucaena leucochepala), dan matoa (Pometia pinnata) yang bertajuk rounded dan mampu mengundang banyak serangga. Kowak malam abu hanya ditemukan di pohon saga (Althenantera pavonina) di sekitar danau LSI yang merupakan habitat bagi anggota suku Ardeidae yang hidup di sekitar badan air ini. Sedangkan wiwik uncuing dalam penelitian ini hanya ditemukan di pohon roda (Hura crepitans).

Dari 11 pohon sengon yang diambil sebagai pohon sampel, rata-rata bisa mengundang 5 jenis burung. Pohon ini memiliki tajuk rounded, percabangan vertical, dan berdaun kecil. Karakteristiknya berkayu lunak memudahkan burung seperti betet biasa (Psittacula alexandri) melubangi batangnya untuk bersarang, dan sangat rentan terhadap serangan hama sehingga mengundang kedatangan burung-burung pemakan serangga (Krisnawati 2011). Sedangkan jenis pohon yang sama sekali tidak bisa mengundang burung berdasarkan hasil pegamatan adalah jambu bol (Syzygium malacense) di petak 6 dan 7, pala (Myristica fragrans) di petak 12, burahol (Stelechocarpus burahol) dan sawo kecik (Manilkara kaukı) di petak 20, rambutan di petak 22, serta damar (Agathis dammara) dan rasamala (Altingea excelsa) pada petak 24. Kesemua jenis yang tidak bisa menarik burung ini disebabkan tidak adanya faktor dari pohon tersebut yang bisa mengundang kehadiran burung, selain itu posisi penanaman yang berada di tengah gedung membatasi akses burung ke pohon tersebut.

\subsubsection{Hubungan arsitektur pohon dengan kehadiran burung}

Hasil analisis regresi linier berganda menunjukkan adanya hubungan kuat antara variabel terikat dengan variabel bebas dengan nilai koefisien korelasi $(R)$ sebesar $73 \%$ serta nilai koefisien determinasi $\left(R^{2}\right)$ sebesar $53,3 \%$. Hasil uji $F$ menunjukkan bahwa model pendugaan yang diajukan dapat diterima karena probabilitasnya kurang dari 0,15. Berdasarkan uji t dapat diketahui bahwa variabel bebas yang berpengaruh nyata terhadap kehadiran burung adalah bentuk percabangan dan keberadaan bunga dengan nilai $\mathrm{P}<0,15$. Dengan demikian, model pendugaannya adalah sebagai berikut.

Keterangan :

$$
Y=0,566+2,777 X_{1}+2,543 X_{2}
$$

$Y=$ Jumlah jenis burung di pohon

$X_{1}=$ Variabel bentuk percabangan

$\mathrm{X}_{2}=$ Variabel keberadaan bunga

Berdasarkan analisis regresi linier berganda, parameter dari pohon yang berpengaruh nyata terhadap kehadiran burung adalah bentuk percabangan dan keberadaan bunga. Meskipun agak berbeda hal ini didukung oleh hasil penelitian Rossana (2005) dan Asmoro (2012) yang menyatakan bahwa tipe arsitektur pohon Attim lebih disukai oleh burung. Tipe arsitektur ini menurut Hale et al. (1978) memiliki percabangan yang menerus (kontinyu) dengan cabang yang monopodial dan ortotropik, menyerupai bentuk percabangan vertical menurut Stevens et al. (1994). Keberadaan bunga sendiri adalah faktor yang sangat menarik burung karena bisa menyediakan nektar dan serangga.

Keberadan buah berdasarkan hasil analisis regresi linier berganda tidak berpengaruh nyata terhadap kehadiran burung, tetapi faktor ini tidak bisa diabaikan karena ditemukan juga beberapa jenis burung pemakan buah. Pohon-pohon yang ditemukan sedang dimakan buahnya oleh burung adalah kersen (Muntingia calabura), beringin (Ficus 
benjamina), buni (Antidesma bunius), dan salam (Syzygium polyanthum). Demikian juga untuk ukuran daun yang tidak berpengaruh nyata, Hirst (2010) menyatakan bahwa pohon berdaun lebar bisa menyediakan perlindungan dari perubahan cuaca dan predator. Tetapi tidak sedikit juga burung yang memanfaatkan pohon berdaun kecil dan sedang, karena memungkinkan burung untuk lebih mudah bermobilisasi.

\subsection{Rekomendasi}

Berdasarkan hasil penelitian ini dihasilkan rekomendasi untuk perencanaan tata hijau di kampus IPB Dramaga, yang bisa juga digunakan pada perencanaan tata hijau secara umum pada lokasi lain. Beberapa rekomendasi yang dihasilkan dari penelitian ini untuk tata hijau di kawasan kampus IPB Dramaga adalah:

1. Penanaman pohon yang mampu menyediakan kebutuhan burung sepanjang tahun Berdasarkan hasil penelitian, dari 99 pohon sampel yang diambil, hanya 19 pohon yang sedang berbunga dan hanya 4 jenis pohon yang dimakan buahnya oleh burung. Menurut Hirst (2010) pemilihan vegetasi yang terbaik adalah yang bisa menyediakan pakan dan tempat berlindung bagi burung. Pemilihan vegetasi khususnya di area urban harus menyediakan kebutuhan burung sepanjang tahun, antara lain tanaman yang memproduksi biji-bijian, beri atau buah lainnya atau nektar, dan dapat menarik serangga (Slattery at al. 2003). Rotasi masa pembungaan pohon yang ditanam menjadi sangat diperlukan agar tersedia bunga sepanjang tahun.

2. Perlu penambahan pohon lokal Jawa Barat ataupun Jawa

Asal pohon harus diperhatikan karena jenis vegetasi asli lebih disukai jenis-jenis binatang asli termasuk burung (Whitten 1999 dan Idilfitri 2012). Hal ini karena nutrisi yang disediakan pohon lokal juga lebih sesuai untuk burung maupun serangga lokal yang bisa menarik burung pemakan serangga.

3. Pengayaan jenis-jenis vegetasi lain selain pohon, seperti semak dan groundcover Stanley Smith Horticultural Trust (2012) menyatakan bahwa dalam penataan vegetasi jenis vegetasi lain, seperti semak sampai tanaman penutup tanah juga harus diperhatikan untuk menyediakan kombinasi, ukuran, dan nutrisi yang tepat untuk burung. Hal ini sesuai dengan kondisi petak 6 dan 11 yang ditemukan jumlah jenis burung paling banyak.

4. Pengelolaan kawasan yang sudah banyak mengundang burung, dan menjadikannya sebagai acuan untuk perencanaan tata hijau di lokasi lain.

Berdasarkan hasil penelitian petak 2, 6, 11, 16, 18, dan 22 bisa menjadi percontohan sistem penanaman dan jenis pohon yang ditanam untuk diaplikasikan di kawasan kampus IPB Dramaga yang lain.

5. Pengaturan jarak tanam pohon

pohon dengan arsitektur sempurna akan lebih berfungsi secara arsitektural dan menambah estetika dibandingkan pohon yang tajuknya bersinggungan karena penanaman yang terlalu rapat.

Terdapat beberapa jenis pohon sampel yang bisa direkomendasikan beserta bentuk tajuknya yang menjadi pertimbangan fungsinya dalam lanskap yang disajikan pada Tabel 2. Pada tabel ini juga terdapat jenis-jenis pohon lain yang tidak memiliki percabangan vertical tetapi juga mampu mengundang kehadiran burung. Jenis-jenis pohon yang direkomendasikan merupakan jenis-jenis pohon yang dalam penelitian ini mampu 
mengundang minimal 5 jenis burung untuk datang. Perlu diperhatikan penggunaan pohon kapuk (Ceiba pentandra) dan roda (Hura crepitans) karena kedua jenis pohon ini mempunyai duri-duri tajam di batangnya.

\section{Simpulan}

Hasil penelitian ini menunjukkan bahwa keanekaragaman pohon yang ditanam di kawasan kampus IPB Dramaga masih terbilang rendah, karena mayoritas adalah pohon bertajuk rounded. Selama penelitian berhasil dijumpai 25 spesies burung yang memanfaatkan 99 pohon sampel secara langsung. Dari sekian banyak spesies burung, terdapat tiga jenis yang memanfaatkan berbagai bentuk arsitektur pohon pada beberapa petak, yaitu cucak kutilang, bondol jawa, dan bondol peking. Dari hasil analisis regresi linier berganda menunjukkan variabel berpengaruh nyata terhadap banyaknya kehadiran jenis burung pada satu pohon adalah bentuk percabangan dan keberadaan bunganya.

Tabel 2. Rekomendasi jenis pohon yang mengundang banyak burung

\begin{tabular}{|c|c|c|c|c|c|}
\hline Bentuk tajuk & Jenis pohon & Nama ilmiah & Fungsi & $\begin{array}{l}\text { Prediksi jenis } \\
\text { burung }\end{array}$ & Ilustrasi \\
\hline \multirow[t]{9}{*}{ Rounded } & Sengon & $\begin{array}{l}\text { Paraserianthes } \\
\text { falcataria }\end{array}$ & Penaung & $\begin{array}{l}1,2,3,4,5,6,7,9, \\
10,11,12,13,15, \\
16,17,18,19,21, \\
22,23\end{array}$ & \\
\hline & Beringin & Ficus sp. & Penaung & $\begin{array}{l}1,2,4,5,6,8,10 \\
11,12,18,20\end{array}$ & \\
\hline & Angsana & Pterocarpus indicus & Penaung & $1,3,4,5,12,20,21$ & \\
\hline & Manggis & $\begin{array}{l}\text { Garcinia } \\
\text { mangostana }\end{array}$ & Penaung & $1,3,4,7,8$ & Sebagai peneduh \\
\hline & Petai & Parkia speciosa & Penaung & $1,2,5,6,7,9$ & \\
\hline & Tanjung & Mimusops elengi & Penaung & $\begin{array}{l}1,2,3,4,5,6,7,9 \\
12,18,22\end{array}$ & \\
\hline & Kelengkeng & Dimocarpus longan & Penaung & $1,2,4,5,14$ & \\
\hline & Rambutan & $\begin{array}{l}\text { Nephelium } \\
\text { lappaceum }\end{array}$ & Penaung & $1,2,5,8,9,12$ & 镸 \\
\hline & $\begin{array}{l}\text { Lamtoro/ } \\
\text { petai cina }\end{array}$ & $\begin{array}{l}\text { Leucaena } \\
\text { leucocephala }\end{array}$ & Penaung & $3,4,7,8,12,23$ & Seb \\
\hline Picturesque & Flamboyan & Delonix regia & $\begin{array}{l}\text { Penaung, } \\
\text { estetik }\end{array}$ & $\begin{array}{l}1,2,3,4,5,7,8 \\
12,21,22\end{array}$ & \\
\hline \multirow[t]{3}{*}{ Spreading } & Kersen & Muntingia calabura & Penaung & $1,2,3,6,12$ & \\
\hline & & & & & Sebagai peneduh un \\
\hline & Ki hujan & Samanea saman & Penaung & $\begin{array}{l}1,3,4,5,6,12,16 \\
18\end{array}$ & \\
\hline \multirow[t]{2}{*}{ Columnar } & Kenari & Canarium comunee & Pengarah & $1,2,3,5,12,21$ & \\
\hline & Salam & $\begin{array}{l}\text { Syzygium } \\
\text { polyanthum }\end{array}$ & Pengarah & $1,2,3,4,12$ & \\
\hline \multirow[t]{3}{*}{ Fastigiate } & Kapuk & Ceiba pentandra & Pengarah & $1,4,9,10,11,13$ & \\
\hline & Pinus & Pinus merkusii & Pengarah & $1,2,3,4,7,8,12$ & \\
\hline & Akasia & Acacia mangium & Pengarah & $1,2,3,5,8,18$ & \\
\hline
\end{tabular}

Keterangan: 1. Cucak kutilang (Pycnonotus aurigaster), 2. Bondol peking (Lonchura punctulata), 3. Bondol jawa (Lonchura leucogastroides), 4. Burung madu sriganti (Cinnyris jugularis), 5. Cipoh kacat (Aegithina tiphia), 6. Cinenen pisang (Orthotomus sutorius), 7. Cinenen jawa (Orthotomus sepium), 8. Gereja erasia (Passer montanus), 9. Tekukur biasa (Streptopelia chinensis), 10. Punai gading (Treron vernans), 11. Betet biasa (Psittacula alexandri), 12. Cabai jawa (Dicaeum trochileum), 13. Gemak loreng (Turnix suscitator), 14. Burung madu kelapa (Anthreptes malacensis), 15. Cekakak sungai (Halcyon chloris), 16. Pelanduk semak (Malacocincla sepiarium), 17. Wiwik kelabu (Cacomantis merulinus), 18. Kacamata biasa (Zosterops palpebrosus), 19. Remetuk laut (Gerygone sulphurea), 20. Kepudang kuduk hitam (Oriolus chinensis), 21. Sepah kecil (Pericrocotus cinnamomeus), 22. Bentet kelabu (Lanius schach), 23. Caladi tilik (Dendrocopos moluccensis), 24. Kowak malam abu (Nycticorax nycticorax), 25. Wiwik uncuing (Cacomantis sepulclaris) 


\section{Daftar Pustaka}

Asmoro A.W.T. 2012. Keanekaragaman Jenis Burung pada Beberapa Cluster Perumahan di Sentul City, Bogor Jawa Barat. Skripsi (tidak dipublikasikan). Bogor (ID): Institut Pertanian Bogor.

Booth NK. 1983. Basic Elements of Landscape Architecture Design. Illinois (US): Waveland Press Inc.

Bridwell FM. 2003. Landscape Plants: Their Identification, Culture, and Use, Second Edition. New York (US): Delmar.

Darjono dan Sudaryanti. 2004. Pengumpulan Data Lapangan Burung. Di dalam: Prijono S.N, Peggie D, Mulyadi. 2004. Pedoman Pengumpulan Data Keanekaragaman Fauna. Bogor (ID): Pusat Penelitian Biologi Lembaga Ilmu Pengetahuan Indonesia

Halle F, Oldeman RAA, Tomlison PB. 1978. Tropical Trees and Forest: an Architectural Analysis. New York (US): Springer-Verlag.

Hirst B. 2012. Ornamental Plants That Improve Bird Habitats. Article Garden. Tersedia pada: http://www.articlegarden.com/Article/Ornamental-Plants-That-Improve-BirdHabitats/3040 (diakses 1 September 2013).

Idilfitri S, Nik Hanita NM. 2012. Role of Ornamental Vegetation for Birds' Habitats in Urban Parks: Case study FRIM, Malaysia. Procedia - Social and Behavioral Sciences. 68 (2012) 894-909

Kurnia I. 2003. Studi Keanekaragaman Jenis Burung untuk Pengembangan Wisata Birdwatching di Kampus IPB Darmaga. Skripsi (tidak dipublikasikan). Bogor (ID): Institut Pertanian Bogor.

Krisnawati H, Varis E, Kallio M, Kanninen M. 2011. Paraserienthes falcataria (L.) Nielsen: Ekologi, Silvikultur Dan Produktivitas. Bogor (ID): CIFOR

Mac Kinnon J, Philips K, Balen V. 2010. Burung-Burung di Sumatera, Jawa, Bali, dan Kalimantan. Bogor (ID): Burung Indonesia

Perrins CM and Birkhead TR. 1983. Teritory Level Biology Avian Ecology. New York (US): Chapman and Hall.

Pettingill OS. 1970. Ornithology in Laboratory and Field. Minnesota (US): Burgess Publisher. Co.

Rosanna Y. 2005. Ruang Terbuka Hijau Sebagai Habitat Burung Di Perkotaan (Kajian Terhadap Habitat Burung dan Estetika Kota) . Tesis (tidak dipublikasikan). Jakarta (ID): Universitas Indonesia.

Slattery BE, Reshetiloff K, dan Zwicker SM. 2003. Native Plants for Wildlife Habitat and Conservation Landscaping. Native Plant Center. Tersedia pada : http://www.nativeplantcenter.net/guides/chesapeaknatives.pdf (diakses 1 September 2013).

Stanley Smith Horticultural Trust. 2012. Trees and Shrubs That Attract Birds. Mortonarb. Tersedia pada: http://www.mortonarb.org/tree-plant-advice/article/868/trees-andshrubs-that-attract-birds.html (diakses 1 September 2013).

Stevens D, Huntington L, and Key R. 1994. Garden Design Construction and Planting. London (GB): Ward Lock

Welty JC. 1982. The Life of Bird. Philadelphia (US): Saunders College Publishing

Whitten T, Roehayat ES, Suraya AA. 1999. Ekologi Jawa dan Bali. Kartikasari SN, Tyas BU, Agus W, penerjemah. Jakarta (ID): Prehallindo. Terjemahan dari: The Ecology of Java and Bali. 